\title{
Morphodynamics and habitat safety in sandy beaches: life-history adaptations in a supralittoral amphipod
}

\author{
Omar Defeo $^{1,2, *}$, Julio Gómez ${ }^{2}$ \\ ${ }^{1}$ CINVESTAV IPN Unidad Mérida, AP 73 Cordemex, 97310 Mérida, Yucatán, Mexico \\ ${ }^{2}$ UNDECIMAR, Facultad de Ciencias, Iguá 4225, PO Box 10773, Montevideo 11400, Uruguay
}

\begin{abstract}
Understanding the relationships between beach morphodynamics and descriptors of macrofauna assemblages has been a major step in theoretical development in sandy beach ecology. However, the role of morphodynamics in shaping life-history traits is still uncertain. Here, we test the predictions of the habitat harshness hypothesis (HHH) on the life-history traits of the sandhopper Atlantorchestoidea brasiliensis, based on information compiled from 7 Uruguayan sandy beaches spanning a continuum from reflective to dissipative states, over a period of almost $2 \mathrm{yr}$. A. brasiliensis showed clear population responses to physical variables in a trend opposite to that predicted by the $\mathrm{HHH}$, including an increase in abundance (total, ovigerous females and juveniles) and individual sizes from dissipative to reflective beaches. A generalized additive model explained $46.1 \%$ of the deviance in sandhopper abundance and retained all 4 physical descriptors in the model as significant. Sandhopper abundance increased with grain size and beach face slope, and decreased with low values of water content and compaction of the sand. Per capita rate of recruitment increased linearly with adult abundance, i.e. there was a positive density-dependent effect of adults on recruitment rates, which exponentially decreased from reflective to dissipative beaches. Only the proportion of ovigerous females increased towards the dissipative domain. We conclude that the HHH did not accurately predict spatio-temporal fluctuations in population features of $A$. brasiliensis, particularly because of a limited appreciation of the role played by life-history strategies in explaining population responses to the environment. Our results have important implications for sandy beach macrofauna, particularly supralittoral organisms, and suggest a novel hypothesis (termed here the 'hypothesis of habitat safety'), which states that the combination of narrow swashes and steep slopes makes reflective beaches a more stable and safer environment for supralittoral species.
\end{abstract}

KEY WORDS: Sandhopper - Atlantorchestoidea brasiliensis - Life history - Sandy beaches · Morphodynamics $\cdot$ Habitat safety

\section{INTRODUCTION}

The morphology and dynamics of microtidal sandy beaches (tidal range $<2 \mathrm{~m}$ ) are a function of sand particle size, breaker height and period, and major topographic features (Short 1996). Interactions between these variables produce a continuum of beach morphodynamic types ranging from reflective to dissipative beaches. The former are narrow and have coarse sedi- ments and steep slopes, whereas dissipative beaches are wide and present fine sands and flat slopes. These interrelated variations in morphodynamic properties have been used to develop ecological theory aiming to explain patterns in macrofauna composition of sandy beaches, as well as to understand the role of morphodynamics in shaping life-history traits in a habitat regarded as one of the harshest of all marine environments. 
Three main non-exclusive hypotheses have been developed to predict how sandy beach communities are structured, as well as how individual species respond to variations in morphodynamics: (1) The 'autoecological hypothesis' (AH), adapted for sandy beaches (McLachlan 1990), states that communities are structured by independent responses of individual species to the physical environment, biological interactions being minimal. (2) In agreement with the $\mathrm{AH}$, but restricted to the intertidal fringe, the 'swash exclusion hypothesis' (SEH) predicts a consistent increase in species richness, abundance and biomass from reflective to dissipative beaches (McArdle \& McLachlan 1991, 1992). The harsher swash climate towards reflective conditions determines the progressive exclusion of species until, in the extreme reflective situation, no intertidal species occur and only supralittoral forms remain (McLachlan et al. 1995). (3) Recently, Gómez \& Defeo (1999) and Defeo et al. $(2001,2003)$ formulated new additions to the original SEH and $\mathrm{AH}$ (both postulated on the community level), to account for predictions on the population level. To this end, the AH and SEH were merged in the 'habitat harshness hypothesis' (HHH: Defeo et al. 2003). The HHH predicts that not only community characteristics such as species richness, but also various population features (abundance, fecundity, growth and survival), increase from reflective to dissipative conditions for species living in the swash zone as well as those immediately landwards of this zone. It is argued that harsh reflective environments force organisms to divert more energy towards maintenance and their populations, therefore have lower abundance, mean individual sizes and weights, growth rates, longevity, fecundity, reproductive output and survival.

Despite the demonstrated importance of morphodynamics in explaining patterns in attributes of sandy beach macrofaunal assemblages, tests of the main predictions of $\mathrm{SEH}$ and $\mathrm{HHH}$ have so far provided dissimilar results: (1) Community analyses primarily show a consistent reduction in species richness and/or abundance towards reflective beaches (McLachlan 1990, Defeo et al. 1992, 2003, Jaramillo \& McLachlan 1993, McLachlan et al. 1993, Brazeiro 1999a, Veloso \& Cardoso 2001, Soares 2003), as a result of increasing environmental severity caused by high swash frequency and velocity, and an increase in erosion-accretion dynamics (Brazeiro 2001). (2) In contrast, population responses to beach morphodynamics have not been as clear. Recent tests of the HHH showed that species that co-occur at beaches with contrasting morphodynamics do not always behave as predicted by the theory. In a multi-scale analysis, Defeo et al. (1997) showed that the abundance and body size of the cirolanid Excirolana braziliensis throughout thousands of $\mathrm{km}$ could not be explained by a simple animal-morphodynamics relationship. Other studies conducted at smaller spatial scales found contradictory results when the $\mathrm{HHH}$ was tested at the population level (Defeo et al. 1997, 2001, 2003, Gómez \& Defeo 1999, Nel et al. 1999, 2001, de la Huz et al. 2002, Cardoso et al. 2003, Contreras et al. 2003). One of the most relevant results is that neither the $\mathrm{SEH}$ nor the $\mathrm{HHH}$ reliably predicted variations in population dynamics and life-history traits of supralittoral forms, which are less influenced by the swash climate and generally have 'autonomous active movement' (sensu Giménez \& Yannicelli 1997) on upper beach levels (Defeo et al. 2003, McLachlan \& Dorvlo 2005).

Methodological weaknesses have also precluded powerful testing of the predictions of these hypotheses at the population level: (1) some studies were based only on 1 or few sampling dates, and thus the effects of morphodynamics on life-history traits could have been biased by instantaneous sampling; (2) others provided a single comparison of only 2 beaches, one reflective and the other dissipative (but see Defeo et al. 1997), and thus the observed population trends cannot be attributed incontestably to morphodynamics, but only to location. Recently, an intensive study (16 beaches sampled bimonthly over a 2 yr period) showed that abundance of the mole crab Emerita brasiliensis significantly increased from reflective to dissipative Uruguayan beaches, lending support to the $\mathrm{HHH}$ (Defeo et al. 2002). Thus, despite years of research effort, remarkably few species have been studied well enough to establish why the existing hypotheses fail to predict population trends on sandy beaches with contrasting morphodynamics.

Talitrid amphipods are usually numerically dominant on exposed sandy beaches (Croker 1967, Brown \& McLachlan 1990, Scapini et al. 1995). The sandhopper Atlantorchestoidea brasiliensis (Dana 1853) ${ }^{1}$ is capable of maintaining populations in the supralittoral to upper midlittoral across the whole morphodynamic spectrum on exposed beaches of Uruguay and Brazil (Defeo et al. 1992, Cardoso \& Veloso 1996). Thus, the species is well suited to evaluate population responses to distinct environmental physical features. Following predictions of the $\mathrm{HHH}$, we investigated whether $A$. brasiliensis shows an increase in abundance, body size and indices of reproduction, and recruitment from reflective to dissipative beaches. To this end, we compare the abundance and life-history traits of $A$. brasiliensis from 7 Uruguayan sandy beaches with contrasting morphodynamics, over almost 2 yr.

\footnotetext{
${ }^{1}$ We follow the recent generic re-allocation of this species by Serejo (2004)
} 


\section{MATERIALS AND METHODS}

Seven oceanic exposed microtidal sandy beaches (tidal range $=0.5 \mathrm{~m}$ ) along $200 \mathrm{~km}$ of the Uruguayan coast were sampled (Table 1). Biological samples and environmental data were collected every 2 mo from July 1999 to April 2001. Three transects were set up perpendicular to the shoreline and spaced $8 \mathrm{~m}$ apart, with sampling units (SUs) on each transect beginning at the base of the dunes and continuing at $4 \mathrm{~m}$ intervals in both seaward and landward directions until at least 2 consecutive SUs yielded no sandhoppers. At each $\mathrm{SU}$, a sheet metal cylinder, $27 \mathrm{~cm}$ in diameter, was used to remove the sediment up to a depth of $40 \mathrm{~cm}$. Each SU was sieved through a $0.5 \mathrm{~mm}$ mesh, and the organisms retained were sexed and measured to the nearest $0.05 \mathrm{~mm}$ from the tip of the cephalon to the end of the telson. Samples with coarse sands were carefully sorted in the laboratory in order to retain all organisms. Sandhoppers were classified into 2 groups: juveniles (non-adults) and adults (males and females). Juveniles presented neither a well-developed second gnathopod (males) nor oostegites (females). Abundance was estimated by the number of individuals per strip transect (IST; ind. $\mathrm{m}^{-1}$ ) (Brazeiro \& Defeo 1996) as either the total or by the population component; ovigerous females, which were defined by the presence of eggs or embryos in the brood pouch, were included.

In each SU, sediment samples were taken for determination of granulometric parameters, sand moisture (water content) and organic matter content. In the latter, macrofauna was first removed from the sediment. Sand compaction (resistance to penetration) was measured in the field using a static piston pocket penetrometer (Herrick \& Jones 2002). The beach face slope (BFS) and beach slope $(S)$ were determined by Emery's profiling technique (Emery 1961). The BFS, located immediately landward of the surf zone, was quantified from the elevation of low tide to the upper limit of swash action (Hughes \& Turner 1999), whereas $S$ was estimated for the entire beach, i.e. from the base of the dunes to the lower limit of the swash zone. After completion of the matrix of physical parameters, the compound indices (dimensionless) of beach state, Dean's parameter $\Omega$ (Short 1996) and beach deposit index (BDI) (Soares 2003), were calculated as follows:

$$
\begin{gathered}
\Omega=\frac{H b \times 100}{W s \times T} \\
\mathrm{BDI}=\frac{1}{S} \times \frac{a}{M z}
\end{gathered}
$$

where $H b$ is breaker height $(\mathrm{m}), W s$ is sand fall velocity $\left(\mathrm{m} \mathrm{s}^{-1}\right), T$ is wave period $(\mathrm{s}), S$ is the beach slope, $a=1.03125 \mathrm{~mm}$ is the median estimate of the sand particle size classification and $\mathrm{Mz}$ is the mean sand particle size $(\mathrm{mm})$. Tables from Gibbs et al. (1971) were used to calculate settling velocities based on particle size. $\Omega$ values $<2$ characterize reflective beaches, whereas $\Omega>5$ define dissipative ones and $2<\Omega<5$ characterize intermediate beach states. Finally, the beach index (BI) formulated by McLachlan \& Dorvlo (2005) was calculated as follows:

$$
\mathrm{BI}=\log _{10}\left(\frac{M z \times \mathrm{TR}}{S}\right)
$$

where TR is the tidal range. $M z$ was expressed in (phi units +1 ), to avoid negative values (McLachlan \& Dorvlo 2005). As in this study $\mathrm{TR}=0.5 \mathrm{~m}$ for all beaches, the BI was driven by variations in the logarithm of the ratio between $M z$ and $S$.

Single relationships between population and physical variables (averaged over the $22 \mathrm{mo}$ ) were modeled by linear or nonlinear fitting, which are more appropri-

Table 1. Full characterization of the main physical variables and the compound indices of beach state (upper and lower levels of

\begin{tabular}{|c|c|c|c|c|c|c|c|}
\hline Beach features & $\begin{array}{l}\text { Sta. Mónica } \\
\text { (SM) }\end{array}$ & $\begin{array}{c}\text { José Ignacio } \\
\text { (JI) }\end{array}$ & $\begin{array}{l}\text { Arachania } \\
\text { (Ara) }\end{array}$ & $\begin{array}{l}\text { Sta. Isabel } \\
\text { (SI) }\end{array}$ & $\begin{array}{l}\text { Pta. del Diablo } \\
\text { (PD) }\end{array}$ & $\begin{array}{l}\text { Achiras } \\
\text { (Ach) }\end{array}$ & $\begin{array}{c}\text { Barra del Chuy } \\
\text { (Bar) }\end{array}$ \\
\hline Latitude south & $34^{\circ} 51^{\prime}$ & $34^{\circ} 49^{\prime}$ & $34^{\circ} 37^{\prime}$ & $34^{\circ} 33^{\prime}$ & $34^{\circ} 02^{\prime}$ & $33^{\circ} 56^{\prime}$ & $33^{\circ} 49^{\prime}$ \\
\hline Grain size (mm) & $0.57-0.61$ & $0.25-0.33$ & $0.40-0.48$ & $0.44-0.60$ & $0.39-0.47$ & $0.24-0.28$ & $0.19-0.23$ \\
\hline Compaction $\left(\mathrm{kg} \mathrm{cm}^{-2}\right)$ & $2.08-2.56$ & $3.29-3.65$ & $2.43-2.93$ & $2.29-2.53$ & $2.25-2.87$ & $3.08-3.74$ & $3.83-4.19$ \\
\hline Water content (\%) & $5.02-7.18$ & $7.00-10.60$ & $6.48-8.88$ & $5.70-7.86$ & $6.39-9.25$ & $7.51-11.93$ & $13.64-14.78$ \\
\hline Organic matter (\%) & $0.11-0.15$ & $0.16-0.28$ & $0.16-0.28$ & $0.31-0.39$ & $0.35-0.47$ & $0.20-0.36$ & $0.17-0.29$ \\
\hline Slope $\left(\mathrm{cm} \mathrm{m}^{-1}\right)$ & $4.00-4.92$ & $3.95-4.90$ & $5.21-6.89$ & $5.99-9.08$ & $4.31-7.12$ & $3.65-5.09$ & $2.39-3.19$ \\
\hline Beach face slope $\left(\mathrm{cm} \mathrm{m}^{-1}\right)$ & $11.39-16.84$ & $4.30-7.24$ & $7.52-11.70$ & $9.87-14.82$ & $29.08-13.81$ & $4.54-7.84$ & $5.22-12.96$ \\
\hline \multicolumn{8}{|l|}{ Compound indices } \\
\hline$\Omega$ & $1.73-3.03$ & $3.10-4.36$ & $1.50-2.56$ & $1.48-2.96$ & $2.20-3.30$ & $3.63-6.17$ & $4.94-7.64$ \\
\hline BDI & $34.23-44.81$ & $72.88-114.24$ & $31.39-49.23$ & $21.15-34.51$ & $132.38-52.06$ & $74.08-146.40$ & $146.60-257.18$ \\
\hline BI & $1.23-1.35$ & $1.45-1.53$ & $1.17-1.33$ & $0.99-1.19$ & $1.16-1.36$ & $1.48-1.56$ & $1.67-1.79$ \\
\hline
\end{tabular}
$95 \%$ confidence intervals) of the 7 Uruguayan oceanic sandy beaches analyzed in this study. Abbreviations for each beach are subsequently used in the figures. Beach states: $\Omega=$ Dean's parameter, BDI $=$ beach deposit index, BI $=$ beach index 
ate than multiple comparison procedures that use discrete categorization of continuous variables to depict patterns (Defeo \& Cardoso 2004). For both $S$ and BFS, the reciprocal of the indices (also termed 'beach gradient') were used for modeling purposes because these perform better statistically (in terms of well-distributed residuals) than raw values. Linear and nonlinear models were fitted, and the model that best explained the relationship between biological and physical variables was selected according to the coefficient of determination $\left(\mathrm{r}^{2}\right)$.

The relationship between abundance of Atlantorchestoidea brasiliensis and several physical variables used simultaneously was modeled through a Generalized Additive Model (GAM) (Hastie \& Tibshirani 1990), because of the nonlinear nature of most relationships (see 'Results'). The following physical variables were selected on the basis of their performance as suitable indicators of species abundance: grain size, beach face slope, sand compaction and sand water content. Based on the rationale provided by Schoeman \& Richardson (2002), abundance estimates (ind. $\mathrm{m}^{-1}$ ) and physical variables from all months were used in order to explicitly account for within-beach variation, and also because the main goal of this analysis was not to detect statistically significant differences among time periods but rather overall relationships between sandhopper abundance and physical variables. A Poisson error distribution was assumed to explain variations in abundance estimates, because the deviance residuals of the model indicated that this was a more appropriate error structure than a Gaussian distribution. This was also found by Schoeman \& Richardson (2002). To avoid including truly redundant variables, yet retaining all important environmental information, the Akaike information criterion (AIC) (McCullagh \& Nelder 1989) was used in a bidirectional stepwise procedure to select the most parsimonious model and to assess the significance of each model term. All predictors were included as smoothed terms, and a spline function of the $j$ th smoothed component (splines) was used to estimate the nonparametric functions. The procedure was implemented through the S-Plus 'step.gam' function (Venables \& Ripley 1999), which enabled the objective selection of significant variables and avoided multicolinearity problems in model development.

\section{RESULTS}

\section{The habitat}

A full characterization of physical variables and indices of the 7 Uruguayan sandy beaches analyzed is shown in Table 1. The steepest beaches (Santa Isabel, Arachania and Santa Mónica) had coarsest sediments and lowest sand compaction and organic matter content, and vice versa. The mean particle size ranged from 0.21 (Barra del Chuy) to $0.59 \mathrm{~mm}$ (Santa Mónica); slope $S$ ranged between 2.79 (Barra del Chuy) and $7.54 \mathrm{~cm} \mathrm{~m}^{-1}$ (Santa Mónica); and sand compaction ranged from 2.32 (Santa Mónica) to $4.01 \mathrm{~kg} \mathrm{~cm}^{-2}$ (Barra del Chuy). Concerning the mean values of composite indices, $\Omega$ varied between 2.03 (Arachania) and 6.29 (Barra del Chuy); BDI between 27.83 (Santa Isabel) and 201.89 (Barra del Chuy); and BI from 1.09 (Santa Isabel) to 1.73 (Barra del Chuy). Relationships between physical variables (Fig. 1) were statistically significant, but the strongest ones were found between sand compaction and (1) $1 / \mathrm{BFS}\left(\mathrm{r}^{2}=\right.$ 0.99; p $<<0.001$ ) and (2) sand grain size $\left(\mathrm{r}^{2}=0.98 ; \mathrm{p}<<0.001\right)$. Most relationships were linear, but several nonlinear models best explained these relationships (Fig. 1). According to Short's (1996) classification based on $\Omega$ and the estimated $95 \%$ confidence intervals (CI) of $\Omega$ provided in Table 1 for each beach, Barra del Chuy and Achiras tended to be dissipative $(\Omega>$ 5); José Ignacio and Punta del Diablo
Fig. 1. Scatter plots of relationships between physical parameters on 7 Uruguayan beaches. ${ }^{*} \mathrm{p}<0.05 ; * * \mathrm{p}<0.01 ; * * * \mathrm{p}<0.001$. Underlined value indicates trend that approached significance $(0.10<\mathrm{p}<0.05)$ 

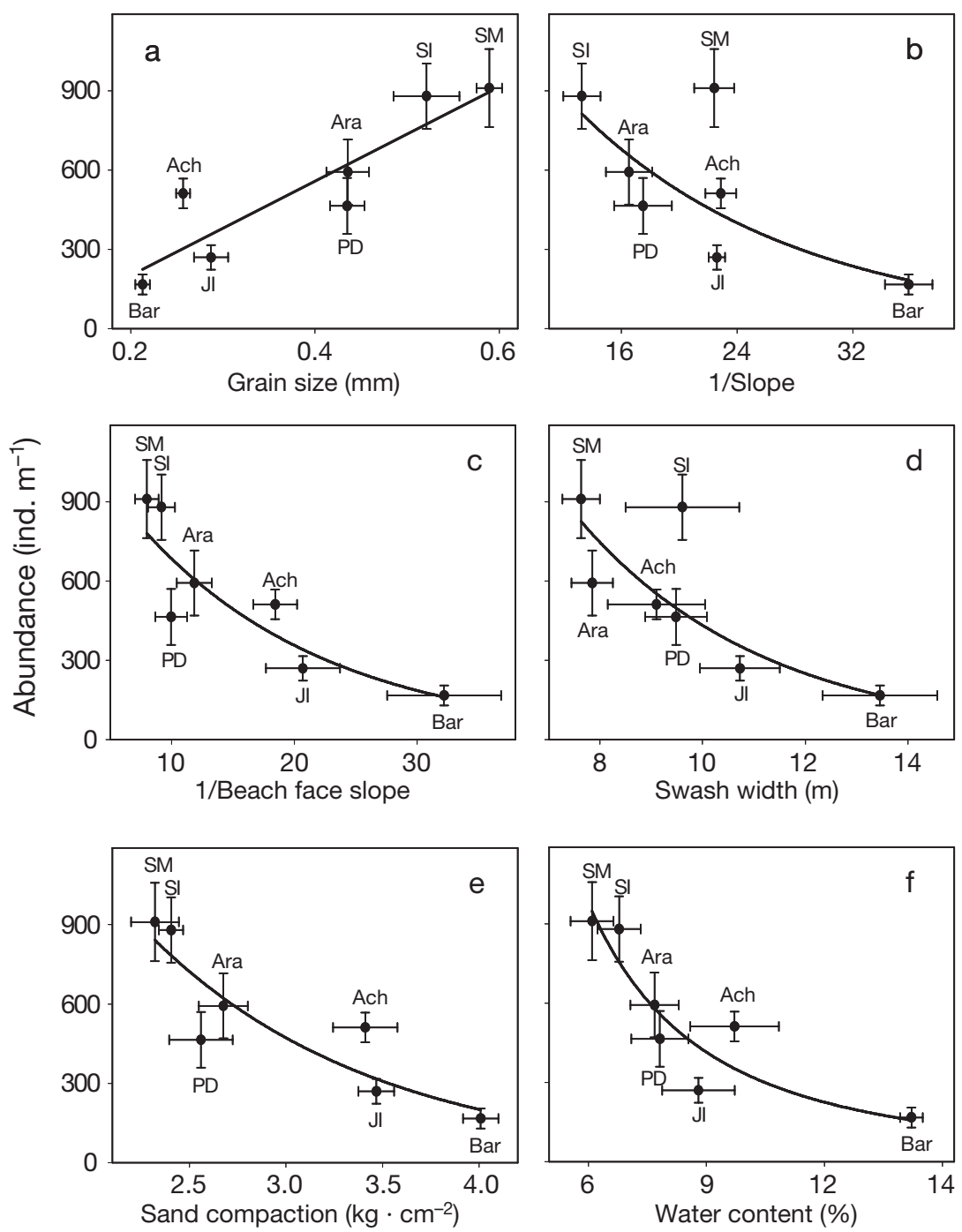

Fig. 2. Atlantorchestoidea brasiliensis. Mean $(\bullet) \pm \mathrm{SE}$ of sandhopper abundance (vertical lines) and physical variables (horizontal lines), together with the models that best fitted the relationship between these variables: (a) grain size; (b) 1/slope; (c) 1/beach face slope; (d) swash width; (e) sand compaction; and (f) sand water content. Abbreviations beside each point refer to the corresponding beaches as in Table 1 were intermediate during the whole period $(2<\Omega<5)$; and Arachania, Santa Isabel and Santa Mónica had the lower CI bound included within truly reflective states (i.e. $\Omega<2$ ).

\section{Abundance}

Contrary to the main predictions of the $\mathrm{HHH}$, the abundance of Atlantorchestoidea brasiliensis increased from dissipative to reflective beaches (Fig. 2), and this was reflected by significant relationships between abundance and several individual physical variables (Table 2, Fig. 2). The best model was the monotonically decreasing exponential function $\operatorname{IST}_{T}=a e^{-b(1 / \mathrm{BFS})}$ $\left(\mathrm{r}^{2}=0.85 ; \mathrm{p}<0.003\right)$, where $\mathrm{IST}_{T}$ is total abundance per strip transect and BFS is the beach face slope (Fig. 2). This remained true for the total population, and for adult males and females separately. Following the same pattern, amphipod abundance was significantly related to the compound indices of beach states $\Omega$, BDI and BI (Table 2, Fig. 3) through nonlinear decreasing functions $\left(0.65<\mathrm{r}^{2}<0.75\right.$; $\mathrm{p}<$ 0.05). In summary: (1) The abundance of A. brasiliensis markedly increased towards reflective beaches. (2) Most relationships were nonlinear. (3) Individual physical variables tended to be more useful predictors of abundance than compound indices.

The GAM explained $46.1 \%$ of the deviance in sandhopper abundance. All physical variables considered in the analysis were significant, as revealed by the AIC stepwise approach, which retained all predictors in the model. The importance of
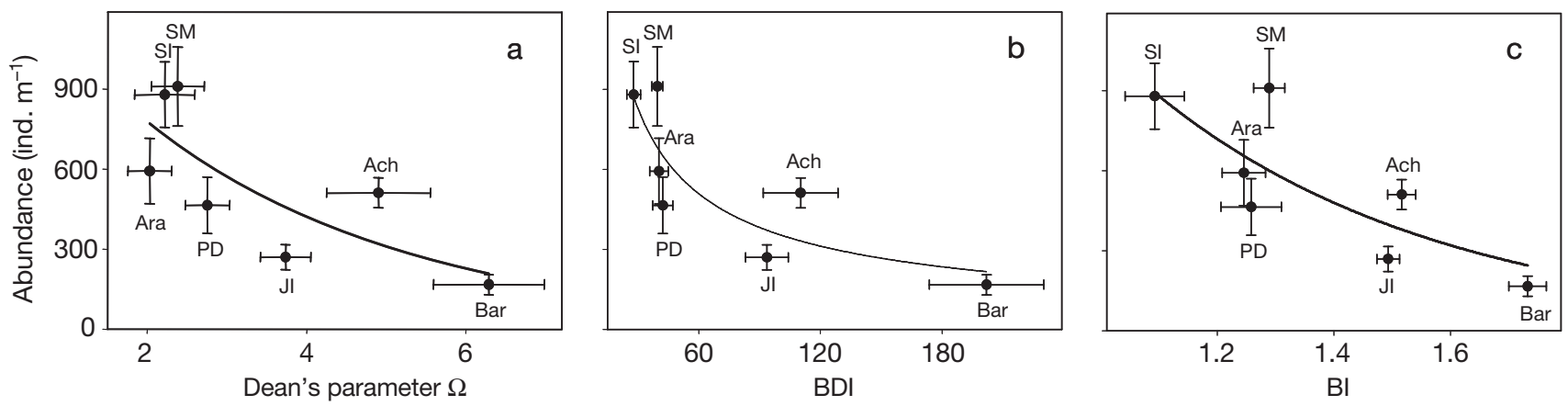

Fig. 3. Atlantorchestoidea brasiliensis. Mean $(\bullet) \pm$ SE of sandhopper abundance (vertical lines) and compound indices of beach state (horizontal lines). In all cases, the best model (solid line) that related a beach index with abundance (highest $\mathrm{r}^{2}$ ) is shown. Regression details are in Table 2. Abbreviations beside each point refer to the corresponding beaches as in Table 1 
the predictors in explaining Atlantorchestoidea brasiliensis abundance, inferred from the AIC statistics in the stepwise model, was, in decreasing order: grain size, beach face slope, water content, and compaction of the sand. The analysis showed that sandhopper abundance increased as grain size increased, reaching a peak at $0.63 \mathrm{~mm}$ (Fig. 4a). The highest abundance was also found at the steepest $\left(>20 \mathrm{~cm} \mathrm{~m}^{-1}\right)$ beach face

Table 2. Atlantorchestoidea brasiliensis. Best linear and nonlinear models estimated between population features and physical variables and compound indices $(\Omega, \mathrm{BDI}$ and BI, see Table 1$) .{ }^{*} \mathrm{p}<0.05 ;{ }^{* *} \mathrm{p}<0.01 ;{ }^{* * *} \mathrm{p}<0.001 ; \mathrm{Mz}$ : mean grain size; $S$ : slope; BFS: beach face slope; SC: sand compaction; SWC: sediment water content; SW: swash width

\begin{tabular}{|c|c|c|c|c|c|c|}
\hline \multirow{2}{*}{ Biological descriptor } & \multicolumn{6}{|c|}{ _ Physical variable - } \\
\hline & $M z(\mathrm{~mm})$ & $1 / S$ & $1 / \mathrm{BFS}$ & SW (m) & $\mathrm{SC}\left(\mathrm{kg} \mathrm{cm}^{-2}\right)$ & SWC $(\%)$ \\
\hline Total abundance (ind. $\mathrm{m}^{-1}$ ) & $y=-a+b x^{* *}$ & $y=a \mathrm{e}^{-b x *}$ & $y=a \mathrm{e}^{-b x * *}$ & $y=a \mathrm{e}^{b X * *}$ & $y=a \mathrm{e}^{-b x * *}$ & $y=a x^{-b_{* *}}$ \\
\hline Ovigerous females (ind. $\mathrm{m}^{-1}$ ) & $y=a+b x^{*}$ & & $y=a \mathrm{e}^{-b x * *}$ & $y=a \mathrm{e}^{-b x *}$ & $y=a \mathrm{e}^{-b x *}$ & $y=a x^{-b * *}$ \\
\hline Juveniles (ind. $\mathrm{m}^{-1}$ ) & $y=-a+b x^{* *}$ & $y=a \mathrm{e}^{-b *}$ & $y=a x^{-b * * *}$ & $y=a \mathrm{e}^{-b x *}$ & $y=a \mathrm{e}^{-b x * *}$ & $y=a x^{-b * *}$ \\
\hline Fertility (juveniles/ovigerous) & $y=a+b x^{* *}$ & & $y=a x^{-b * *}$ & & $y=a x^{-b * * *}$ & $y=a x^{-b *}$ \\
\hline Proportion ovigerous (\%) & $y=a x^{-b *}$ & & $y=a x^{-b * *}$ & $y=-a+b x^{*}$ & $y=-a+b x^{* *}$ & $y=a x^{-b *}$ \\
\hline Mean ovigerous size (mm) & & $y=\mathrm{ae}^{-b x *}$ & & & & $y=a \mathrm{e}^{-b x *}$ \\
\hline Largest male (mm) & & $y=a \mathrm{e}^{-b x *}$ & & & & $y=a \mathrm{e}^{-b x *}$ \\
\hline \multirow[t]{3}{*}{ Largest female $(\mathrm{mm})$} & & $y=a \mathrm{e}^{-b x *}$ & & & & $y=a \mathrm{e}^{-b x *}$ \\
\hline & \multicolumn{6}{|c|}{ Compound index } \\
\hline & & $\Omega$ & \multicolumn{2}{|c|}{ BDI } & BI & \\
\hline Abundance (ind. $\mathrm{m}^{-1}$ ) & & $y=a \mathrm{e}^{-b x *}$ & \multicolumn{2}{|c|}{$y=a x^{-b *}$} & $y=a \mathrm{e}^{-b x *}$ & \\
\hline Ovigerous females (ind. $\mathrm{m}^{-1}$ ) & & & \multicolumn{2}{|c|}{$y=a \mathrm{e}^{-b x *}$} & $y=a \mathrm{e}^{-b x *}$ & \\
\hline Juveniles (ind. $\mathrm{m}^{-1}$ ) & & $y=a \mathrm{e}^{-\mathrm{bx} * *}$ & \multicolumn{2}{|c|}{$y=a x^{-b * *}$} & $y=a \mathrm{e}^{-b x * *}$ & \\
\hline Fertility (juveniles/ovigerous) & & $y=a x^{-b *}$ & \multicolumn{2}{|c|}{$y=a x^{-b *}$} & $y=a \mathrm{e}^{-b x *}$ & \\
\hline Proportion ovigerous (\%) & & & \multicolumn{2}{|c|}{$y=a+b x^{*}$} & $y=-a+b x^{*}$ & \\
\hline Mean ovigerous size (mm) & & $y=a \mathrm{e}^{-b x *}$ & \multicolumn{2}{|c|}{$y=a \mathrm{e}^{-b x *}$} & $y=a \mathrm{e}^{-b x *}$ & \\
\hline \multicolumn{2}{|l|}{ Largest male (mm) } & & \multirow{2}{*}{\multicolumn{2}{|c|}{$y=a \mathrm{e}^{-b x *}$}} & & \\
\hline Largest female (mm) & & $y=a \mathrm{e}^{-b x *}$ & & & & \\
\hline
\end{tabular}
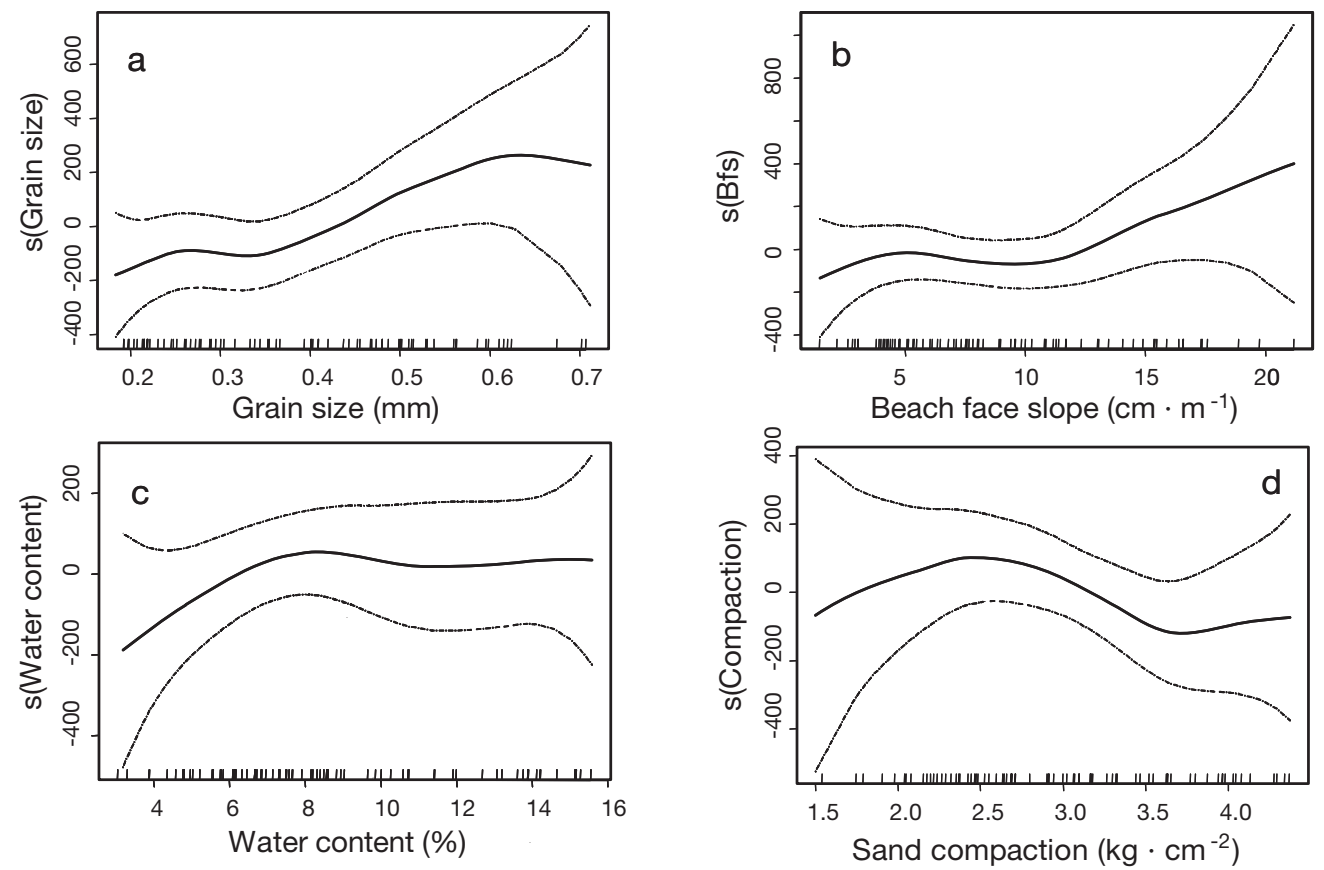

Fig. 4. Atlantorchestoidea brasiliensis. Results of the Generalized Additive Model showing the relationship (solid line) between A. brasiliensis abundance and each meaningful physical predictor, in order of importance: (a) grain size, (b) beach face slope, (c) water content, and (d) sand compaction. Dashed lines indicate twice the pointwise asymptotic standard errors of the estimated curve, and the 'rug plots' on the $x$-axis indicate the range of variables over which measurements were taken 
slopes (Fig. 4b) and low (8\%) water content, after which a plateau of abundance occurred (Fig. 4c). In terms of sand compaction (Fig. 4d), the strong nonlinear effect denoted an abundance peak at ca. $2.5 \mathrm{~kg}$ $\mathrm{cm}^{-2}$, declining towards lower and higher compaction values.

\section{Reproduction, recruitment and body size}

Contrary to the main predictions of the $\mathrm{HHH}$, the abundance of ovigerous females increased from dissipative to reflective beaches. The best model was the monotonically decreasing exponential function of the form $\operatorname{IST}_{O V}=a e^{-b S W C}$ (Fig. 5a), where $\operatorname{IST}_{O V}$ is the abundance of ovigerous females and SWC is the sand water content $\left(\mathrm{r}^{2}=0.89 ; \mathrm{p}<0.005\right)$. Only the proportion of ovigerous females $\left(P_{O V}\right)$ clearly followed $\mathrm{HHH}$ predictions, significantly increasing from the reflective to the dissipative domain (Fig. 5b); the best model was a linear function of sand compaction (SC) $P_{O V}=a+(b \times$ SC) $\left(\mathrm{r}^{2}=0.83 ; \mathrm{p}<0.005\right)$. Consequently, $P_{O V}$ was inversely related to total abundance, following the monotonically decreasing exponential function $P_{O V}=$ $a \times e^{-b \operatorname{IST}_{T}}\left(\mathrm{r}^{2}=0.63 ; \mathrm{p}<0.01\right)$, indicating a significant increase in the relative representation of ovigerous females towards dissipative beaches. The mean size of ovigerous females showed a consistent increase from
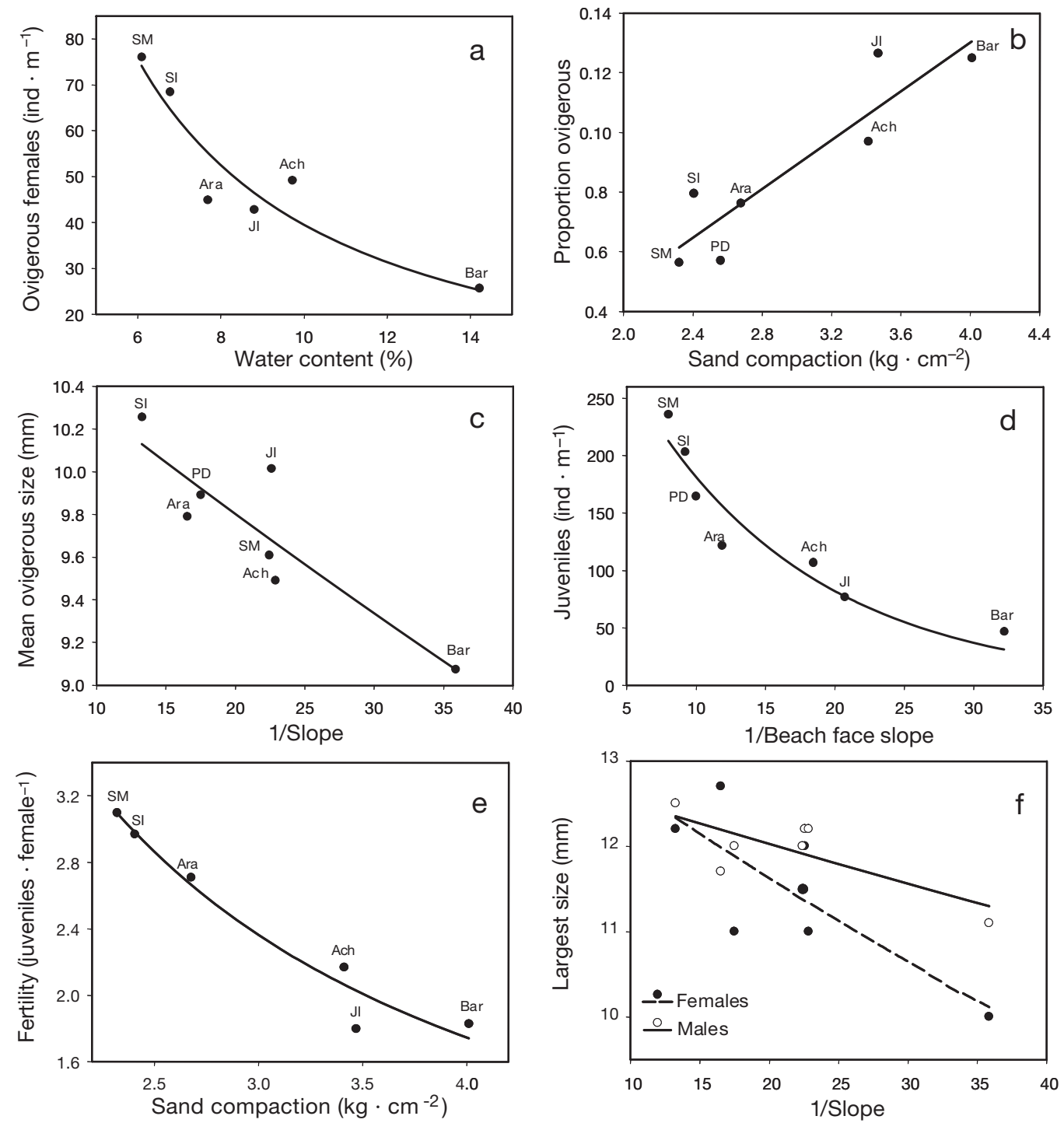

Fig. 5. Atlantorchestoidea brasiliensis. Relationship between population descriptors and physical variables: (a) abundance; (b) proportion, and (c) mean individual size of ovigerous females; (d) juvenile abundance; (e) fertility; and (f) largest individual size of (•) females and (০) males. Abbreviations beside each point refer to the corresponding beaches as in Table 1 . In all cases, the best model (solid line) that related a physical variable with a biotic one (highest $\mathrm{r}^{2}$ ) is shown. Regression details are in Table 2 
dissipative to reflective beaches, ranging from $9.07 \mathrm{~mm}$ (Barra del Chuy) to $10.26 \mathrm{~mm}$ (Santa Isabel), and the best model was $L_{O V}=a \times e^{-b 1 / S}\left(\mathrm{r}^{2}=0.67 ; \mathrm{p}=\right.$ $0.024)$, where $L_{O V}$ is the mean size ( $\mathrm{mm}$ ) of ovigerous females and $S$ the beach slope (Fig. 5c). Following the same trend observed in ovigerous females, juvenile abundance, taken to be a direct measure of recruitment success, decreased exponentially towards dissipative beaches with the reciprocal of BFS as follows: $\mathrm{IST}_{J U V}=a(1 / \mathrm{BFS})^{-b}\left(\mathrm{r}^{2}=0.96 ; \mathrm{p}<0.0001\right.$ : Fig. 5d).

The per capita rate of recruitment or fertility (i.e. juveniles per ovigerous female) increased linearly with adult abundance $\left(\operatorname{IST}_{A D}\right)$ as follows: $\operatorname{IST}_{(J U V / O V)}=a+$ $\left(b \times \mathrm{IST}_{A D}\right)\left(\mathrm{r}^{2}=0.94 ; \mathrm{p}<0.002\right) ;$ i.e. there was a positive density-dependent effect of adult abundance on reproductive rates. A maximum of 3.1 juveniles per female was estimated for the reflective Santa Mónica, whereas a value 1.7 times lower (ca. 1.8 juveniles female $^{-1}$ ) was estimated for José Ignacio and Barra del Chuy. Fertility estimates were strongly correlated with several physical variables, notably as a monotonically decreasing function of sand compaction $\left(\mathrm{r}^{2}=0.95\right.$; $\mathrm{p}<$ 0.001: Table 2, Fig. 5e). Two clear groups were identified in Fig. 5e: (1) high-fertility sandhoppers on reflective beaches with low sand compaction (ca. $2.5 \mathrm{~kg}$ $\mathrm{cm}^{-2}$ ) and (2) low-fertility sandhoppers on intermediate/dissipative beaches with high sand compaction $\left(\geq 3.4 \mathrm{~kg} \mathrm{~cm}^{-2}\right)$.

Largest individual sizes increased significantly from dissipative to reflective beaches, and this was consistent for both sexes (Fig. 5f). Sandhopper sizes were significantly related to physical variables, notably $1 / S$, through nonlinear decreasing models (Table 2: $\mathrm{r}^{2}=$ $0.59, \mathrm{p}<0.05$ for males; $\mathrm{r}^{2}=0.65, \mathrm{p}<0.05$ for females). An ANCOVA, performed with the reciprocal of slope as the covariate, revealed a statistical lack of significance in a comparison of the largest body size between sexes (homogeneity of slopes: $F_{1,10}=1.79, \mathrm{p}=0.21$; main effect: $F_{1,11}=3.10 ; \mathrm{p}=0.11$ ). Despite the consistent trends, males tended to be larger towards dissipative beaches (Fig. 5f).

\section{DISCUSSION}

Atlantorchestoidea brasiliensis showed strong patterns in abundance and life-history traits throughout a morphodynamic continuum along $200 \mathrm{~km}$ of sandy coast. Results obtained from 7 beaches repeatedly over almost 2 yr demonstrated that $A$. brasiliensis responded systematically to beach morphodynamics in a manner opposite to that predicted by the HHH. Total abundance, body size, and reproduction and recruitment success increased significantly from dissipative to reflective beaches. These trends were explained by variations in individual physical variables as well as those in compound indices $(\Omega, \mathrm{BI}$ and BDI) that take into account multiple features of the beach ecosystem. However, the best statistical relationships were found with individual physical factors, as previously shown by Nel (2001) and McLachlan \& Dorvlo (2005).

Our results are consistent with the hypothesis that population features associated with fitness in supralittoral peracarids exhibiting direct development are optimized towards reflective beaches (Defeo et al. 1997, Gómez \& Defeo 1999), which have been traditionally considered as the harshest sandy beach environment. Contrary to the predictions of the $\mathrm{HHH}$ and $\mathrm{SEH}$, the total abundance of Atlantorchestoidea brasiliensis significantly increased from dissipative to reflective beaches. This finding was demonstrated both by single relationships and by a model-building approach (i.e. GAM). The GAM showed that sandhopper abundance was clearly related to each environmental predictor after removing the effect of all other predictor variables. The model predicted highest abundances at medium to coarse grain sizes, steep beach face slopes and low values of water content and sediment compaction of the sand, all indicative of beach reflectiveness. Gómez \& Defeo (1999) also found higher abundance, growth and survival of $A$. brasiliensis on the reflective beach Arachania than on the dissipative Barra del Chuy (beaches included here but using datasets spaced 3 yr apart). Higher abundances towards reflective beaches were also found by Veloso \& Cardoso (2001) for the same species in beaches of Rio de Janeiro (Brazil) and by Contreras et al. (2003) for the amphipod Orchestoidea tuberculata in Chile. In South Africa, the supralittoral amphipod Talorchestia capensis showed significantly higher abundance on a beach with a pebble berm above the water mark than on an exposed dissipative beach (Schoeman et al. 2003). Abundance of ovigerous females and juveniles, as well as body size (both sexes and ovigerous females) also showed a clear increase from dissipative to reflective domains, following the reverse of the trend predicted by the HHH. This supports previous findings by Gómez \& Defeo (1999), who reported greater brood size, egg production potential and recruitment levels among sandhoppers on a reflective beach than those on a dissipative beach. Ovigerous females and juveniles of $O$. tuberculata in Chile were also less abundant on a dissipative beach (Contreras et al. 2003). These consistent trends were also reported for other supralittoral peracarids. The ovoviviparous isopod Excirolana braziliensis showed greater abundance and larger body sizes on reflective than dissipative beaches all along Atlantic sandy beaches of South America (Cardoso \& Defeo 2003, 2004), notably Brazilian (Veloso \& Cardoso 2001) and Uruguayan (Defeo et al. 1992, 1997, 
Defeo \& Martínez 2003) beaches. McLachlan (1990) also found that the individual size of crustaceans increased from dissipative to reflective beaches.

The above patterns are in clear contradiction to those found for truly intertidal species. Indeed, abundance, body size, growth, survival and burrowing perfomance tend to increase towards dissipative beaches, as documented for the sand crabs Emerita analoga (Dugan et al. 1994, Dugan \& Hubbard 1996, Brazeiro 1999b) and E. brasiliensis (Defeo \& Cardoso 2002, Defeo et al. 2002), and clams of the genus Donax (McLachlan et al. 1995, 1996, Nel et al. 2001, de la Huz et al. 2002). Thus, we argue that the SEH and $\mathrm{HHH}$ have often been accepted almost uncritically wherever (1) community descriptors are related to morphodynamics, and (2) population properties are analyzed in truly intertidal forms directly affected by the swash climate. On the contrary, supralittoral species, notably peracarids capable of maintaining populations across the whole morphodynamic spectrum, exhibit greater fitness indicators (higher abundance, growth and fertility rates) on reflective beaches.

The discrepancy between patterns provided for intertidal suspension feeders and supralittoral forms appears to be related to life-history strategies (see also Defeo et al. 2003): (1) Species that showed relative independence of swash climate effects and no clear responses to beach type mainly occur in the supralittoral and high midlittoral levels of the beach (e.g. the peracarids Atlantorchestoidea and Excirolana). These peracarids have direct development (small reproductive effort, aplanktonic larval phase and parental care of eggs/embryos). (2) On the other hand, the species that mainly follow predictions of the $\mathrm{SEH}$ and $\mathrm{HHH}$ are mainly represented by intertidal forms, notably (a) broadcast spawners with external fertilization and planktonic larvae (e.g. clams), and (b) anomuran crabs with brooding females and planktonic larvae. These intertidal species are affected throughout their entire life span by the swash climate. Thus, our results suggest that the theoretical body already developed in sandy beach ecology needs some refinement concerning the explanation of species responses to the physical environment, particularly for supralittoral species.

Only the proportion of ovigerous females $\left(P_{O V}\right)$ increased towards the dissipative domain. Concurrent changes in $P_{O V}$ and reproductive characteristics may explain this large-scale pattern, thus depicting interconnected reproductive characteristics. Indeed, the significant increase in the relative representation of ovigerous females towards dissipative beaches could compensate for their lower abundance. Additional analyses with the information provided here showed that the per capita reproductive rates, i.e. the number of juveniles produced per female, was inversely related to $P_{O V}\left(\mathrm{r}^{2}=-0.93 ; \mathrm{p}<0.0017\right)$. This suggests that on reflective beaches, the reduced $P_{O V}$ is succesfully counteracted by the increasing fertility of ovigerous females with largest sizes.

The combination of narrow swashes and steep slopes generate accretional states, where wave energy is reflected back to sea from waves breaking directly on the steep beach face (Short 1999), thus making reflective beaches safer environments for species living outside the swash climate. Microtidal sandy beaches are wavedominated and subject to unpredictable, strong and dramatic short-term increases in tide ranges (i.e. up to the sand dunes) generated by storm surges, barometric tides and wind-driven surf off the ocean (Brazeiro \& Defeo 1996). These unpredictable events usually determine high mortality rates common of benthic macrofauna on dissipative beaches (reviewed in Defeo 2003). Higher natural mortality on dissipative beaches, estimated by Gómez \& Defeo (1999), was mainly explained by unpredictability in barometric tides and higher predation rates by birds, arachnids, crabs and insects, which are abundant in dissipative beaches (Brown \& McLachlan 1990). Lower mortality rates on reflective beaches were explained by coastline stability; intrusion of wave-dominated tides is mitigated by the steep face slope on the lower shore, making incoming waves and backwash collide (Gómez \& Defeo 1999). This should imply habitat-driven shifts in sandhopper abundance and behaviour according to beach morphodynamics; substantial variations in sandhopper orientation (Scapini et al. 1995) and in the circadian rhythm of locomotor activity (Nardi et al. 2003) were found as a function of coast stability and dynamics.

Following the mesoscale hypothesis of environmental favourability for sandy beach populations suggested by Caddy \& Defeo (2003), we predict that microtidal reflective beaches constitute more stable and safer shores for supralittoral species, because their risk of immersion is substantially lower there than on dissipative beaches. This statement has physical and biological support: concerning the former, Short (1999, p. 195) defined modally reflective beaches as the most stable of the 3 beach types (i.e. dissipative, intermediate and reflective), with stable backshores given by very low backshore mobility (see also his Table 1, p. 178). This is shown in our Fig. $2 \mathrm{c}$; the beach face slope (BFS) variability clearly increased from reflective beaches (with the highest sandhopper abundance) to dissipative ones. Thus, reflective environments appear to favour rather than negatively affect fitness features of supralittoral forms. This constitutes our hypothesis of habitat safety for supralittoral forms inhabiting sandy beaches.

Much work remains before the hypothesis of habitat safety could be tested successfully under several envi- 
ronmental conditions and species, but in the end it seems likely that single-factor explanations for why sandy beach populations are regulated will prove unsatisfactory. Given the complexity of life histories and processes that underlie biological responses, we argue against a simple relationship between morphodynamics and population features. In this context, existing hypotheses have limited appreciation of the role played by the variety of life-history strategies in explaining sand beach population responses to the environment. As the large interspecific variation in life-history traits suggests that different species could be controlled by different physical factors, we cannot ignore the fact that variations in life-history traits have great potential for expanding our view of the mechanisms controlling sandy beach population regulation patterns in these physically stressful habitats.

Acknowledgements. This paper is part of the PhD thesis of J.G. We wish to express our gratitude to the 'Benthic Ecology Group' of UNDECIMAR for field and laboratory assistance. Three anonymous referees gave useful suggestions that substantially improved the final manuscript. Financial support from CONICYT (Projects No. 1018 and 4034), PDT (Project $\mathrm{S} / \mathrm{C} / \mathrm{OP} / 07 / 49)$ and PEDECIBA is acknowledged.

\section{LITERATURE CITED}

Brazeiro A (1999a) Community patterns in sandy beaches of Chile: richness, composition, distribution and abundance of species. Rev Chil Hist Nat 72:93-105

Brazeiro A (1999b) Patrones comunitarios en ensambles de macroinvertebrados intermareales de playas arenosas expuestas de Chile: exploración de procesos y mecanismos subyacentes. PhD thesis, Pontificia Universidad Católica de Chile, Santiago

Brazeiro A (2001) The relationship between species richness and morphodynamics in sandy beaches: which are the underlying factors? Mar Ecol Prog Ser 224:35-44

Brazeiro A, Defeo O (1996) Macroinfauna zonation in microtidal sandy beaches: is it possible to identify patterns in such variable environments? Estuar Coast Shelf Sci 42: 523-536

Brown AC, McLachlan A (1990) Ecology of sandy shores. Elsevier, Amsterdam

Caddy JF, Defeo O (2003) Enhancing or restoring the productivity of natural populations of shellfish and other marine invertebrate resources. FAO Fish Tech Pap 448. FAO, Rome

Cardoso RS, Defeo O (2003) Geographical patterns in reproductive biology of the pan-American sandy beach isopod Excirolana braziliensis. Mar Biol 143:573-581

Cardoso RS, Defeo O (2004) Biogeographic patterns in life history traits of the pan-American sandy beach isopod Excirolana braziliensis. Estuar Coast Shelf Sci 61:559-568

Cardoso RS, Veloso VG (1996) Population biology and secondary production of the sandhopper Pseudorchestoidea brasiliensis (Amphipoda: Talitridae) at Prainha Beach, Brazil. Mar Ecol Prog Ser 142:111-119

Cardoso RS, Veloso VG, Caetano HS (2003) Life history of Emerita brasiliensis (Decapoda: Hippidae) on two beaches with different morphodynamic characteristics. J Coastal Res (Special Issue 35):392-401

Contreras H, Jaramillo E, Duarte C, McLachlan A (2003) Population abundances, growth and natural mortality of the crustacean macroinfauna at two sand beach morphodynamic types in southern Chile. Rev Chil Hist Nat 76: 543-561

Croker RA (1967) Niche diversity in five sympatric species of intertidal amphipods (Crustacea: Haustoriidae). Ecol Monogr 49:746-751

Defeo O (2003) Marine invertebrate fisheries in sandy beaches: an overview. J Coastal Res (Special Issue 35): 56-65

Defeo O, Cardoso R (2002) Macroecology of population dynamics and life history traits of the mole crab Emerita brasiliensis in Atlantic sandy beaches of South America. Mar Ecol Prog Ser 239:169-179

Defeo O, Cardoso R (2004) Latitudinal patterns in abundance and life-history traits of the mole crab Emerita brasiliensis on South American sandy beaches. Divers Distrib 10: 89-98

Defeo O, Martínez G (2003) The habitat harshness hypothesis revisited: life history of the isopod Excirolana braziliensis in sandy beaches with contrasting morphodynamics. J Mar Biol Assoc UK 83:331-340

Defeo O, Jaramillo E, Lyonnet A (1992) Community structure and intertidal zonation of the macroinfauna in the Atlantic coast of Uruguay. J Coastal Res 8:830-839

Defeo O, Brazeiro A, de Alava A, Riestra G (1997) Is sandy beach macroinfauna only physically controlled? Role of substrate and competition in isopods. Estuar Coast Shelf Sci 45:453-462

Defeo O, Gómez J, Lercari D (2001) Testing the swash exclusion hypothesis in sandy beach populations: the mole crab Emerita brasiliensis in Uruguay. Mar Ecol Prog Ser 212: $159-170$

Defeo O, Lercari D, Celentano E, Lozoya JP, Martínez G (2002) Pautas biológico-pesqueras para el desarrollo de una pesquería artesanal del crustáceo Emerita brasiliensis en la costa atlántica uruguaya. Tech Rep CSIC. Universidad de la República, Montevideo

Defeo O, Lercari D, Gómez J (2003) The role of morphodynamics in structuring sandy beach populations and communities: what should be expected? J Coastal Res (Special Issue 35):352-362

de la Huz R, Lastra M, López J (2002) The influence of sediment grain size on burrowing, growth and metabolism of Donax trunculus L. (Bivalvia: Donacidae). J Sea Res 47: 85-95

Dugan JE, Hubbard DM (1996) Local variation in populations of the sand crab Emerita analoga on sandy beaches in southern California. Rev Chil Hist Nat 69:579-588

Dugan JE, Hubbard DM, Wenner AM (1994) Geographic variation in life history of the sand crab, Emerita analoga (Stimpson) on the California coast: relationships to environmental variables. J Exp Mar Biol Ecol 181:255-278

Emery KO (1961) A simple method of measuring beach profiles. Limnol Oceanogr 6:90-93

Gibbs RJ, Matthews MD, Link DA (1971) The relationship between sphere size and settling velocity. J Sediment Petrol 41:7-18

Giménez L, Yannicelli B (1997) Variability of zonation patterns in temperate microtidal Uruguayan beaches with different morphodynamic types. Mar Ecol Prog Ser 160: 197-207

Gómez J, Defeo O (1999) Life history of the sandhopper Pseudorchestoidea brasiliensis (Amphipoda) in sandy 
beaches with contrasting morphodynamics. Mar Ecol Prog Ser 182:209-220

Hastie T, Tibshirani R (1990) Generalized additive models. Champan \& Hall, London

Herrick JE, Jones TL (2002) A dynamic cone penetrometer for measuring soil penetration resistance. Soil Sci Soc Am J 66:1320-1324

Hughes MG, Turner I (1999). The beachface. In: Short AD (ed) Handbook of beach and shoreface morphodynamics. John Wiley \& Sons, New York, p 119-144

Jaramillo E, McLachlan A (1993) Community and population responses of the macroinfauna to physical factors over a range of exposed sandy beaches in south-central Chile. Estuar Coast Shelf Sci 37:615-624

McArdle S, McLachlan A (1991) Dynamics of the swash zone and effluent line on sandy beaches. Mar Ecol Prog Ser 76:91-99

McArdle S, McLachlan A (1992) Sandy beach ecology: swash features relevant to the macrofauna. J Coastal Res 8: 398-407

McCullagh P, Nelder JA (1989) Generalized linear models. Chapman \& Hall, London

McLachlan A (1990) Dissipative beaches and macrofauna communities on exposed intertidal sands. J Coastal Res 6 : $57-71$

McLachlan A, Dorvlo A (2005) Global patterns in sandy beach macrobenthic communities. J Coastal Res 21(5):in press

McLachlan A, Jaramillo E, Donn TE, Wessels F (1993) Sand beach macrofauna communities: a geographical comparison. J Coastal Res (Special Issue 15):27-38

McLachlan A, Jaramillo E, Defeo O, Dugan J, de Ruyck A, Coetzee P (1995) Adaptations of bivalves to different beach types. J Exp Mar Biol Ecol 187:147-160

McLachlan A, Dugan JE, Defeo O, Ansell AD, Hubbard DM, Jaramillo E, Penchaszadeh P (1996) Beach clam fisheries. Oceanogr Mar Biol Annu Rev 34:163-232

Nardi M, Morgan E, Scapini F (2003) Seasonal variation in the free-running period in two Talitrus saltator populations from Italian beaches differing in morphodynamics and human disturbance. Estuar Coast Shelf Sci 58(Suppl): 199-206

Editorial responsibility: Otto Kinne (Editor-in-Chief), Oldendorf/Luhe, Germany
Nel P (2001) Physical and biological factors structuring sandy beach macrofauna communities. PhD thesis, University of Cape Town

Nel R, McLachlan A, Winter D (1999) The effect of sand particle size on the burrowing ability of the beach mysid Gastrosaccus psammodytes Tattersall. Estuar Coast Shelf Sci 48:599-604

Nel R, McLachlan A, Winter DPE (2001) The effect of grain size on the burrowing of two Donax species. J Exp Mar Biol Ecol 265:219-238

Scapini F, Buiatti M, De Matthaeis E, Mattoccia M (1995) Orientation behaviour and heterozygosity of sandhopper populations in relation to stability of beach environments. J Evolution Biol 8:43-52

Schoeman DS, Richardson AJ (2002) Investigating biotic and abiotic factors affecting recruitment of an intertidal clam on an exposed sandy beach using a generalized additive model. J Exp Mar Biol Ecol 276:67-81

Schoeman DS, Wheeler M, Wait M (2003) The relative accuracy of standard estimators for macrofaunal abundance and species richness derived from selected intertidal transect designs used to sample exposed sandy beaches. Estuar Coast Shelf Sci 58(Suppl):5-16

Serejo CS (2004) Talitridae (Amphipoda, Gammaridea) from the Brazilian coastline. Zootaxa 646:1-29

Short AD (1996) The role of wave height, period, slope, tide range and embaymentisation in beach classifications: a review. Rev Chil Hist Nat 69:589-604

Short AD (1999) Wave-dominated beaches. In: Short AD (ed) Handbook of beach and shoreface morphodynamics. John Wiley \& Sons, New York, p 119-144

Soares AG (2003) Sandy beach morphodynamics and macrobenthic communities in temperate, subtropical and tropical regions - a macroecological approach. PhD thesis, University of Port Elizabeth, South Africa

Veloso VG, Cardoso RS (2001) The effect of morphodynamics on the spatial and temporal variation of the macrofauna of three sandy beaches on the Rio de Janeiro state, Brazil. J Mar Biol Assoc UK 81:369-375

Venables WN, Ripley BD (1999) Modern applied statistics with S-Plus, 3rd edn. Springer-Verlag, London

Submitted: September 27, 2004; Accepted: January 18, 2005 Proofs received from author(s): May 4, 2005 